\title{
Uterine nitric oxide levels and isofluopredone treatment effect in mares susceptible to persistent post-breeding endometritis
}

\author{
C.A. Wolf ${ }^{1}$, E. Malschitzky ${ }^{2}$, I.C. Bustamante-Filho ${ }^{3}$, M.I.M. Jobim ${ }^{1}$, R.C. Mattos ${ }^{1,4}$ \\ ${ }^{1}$ Reprolab, Faculdade de Veterinária, UFRGS, Porto Alegre, RS, Brazil. \\ ${ }^{2}$ Curso de Medicina Veterinária, ULBRA, Canoas, RS, Brazil. \\ ${ }^{3}$ Centro de Ciências Biológicas e da Saúde, Centro Universitário UNIVATES, Lajeado, RS, Brazil.
}

\begin{abstract}
Transient endometritis is a normal consequence of breeding and results from uterine contamination with both semen and bacteria. The modulation of the inflammatory response with the use of isoflupredone has been proposed as efficient for the treatment of endometritis by increasing pregnancy rates. The aim of the current study was to determine the effects of isoflupredone on nitric oxide (NO) levels in uterine samples from mares susceptible to persistent postbreeding endometritis, presenting or not the infectious process. Seven consecutive estrous cycles were induced in 11 mares, being the first one used as control (no treatment). All mares were submitted to the following four treatments: treatment 1: control, treatment 2: glucocorticoid (GC) treatment $(20 \mathrm{mg}$ isoflupredone acetate) every $12 \mathrm{~h}$, for three consecutive days, treatment 3: infected treatment (intrauterine infusion of $1 \times 10^{9} \mathrm{CFU} / \mathrm{ml}$ Streptococcus equi subsp. zooepidemicus), treatment 4: combination of $\mathrm{GC}+$ infected treatment (infusion of bacteria $24 \mathrm{~h}$ after the first $\mathrm{GC}$ treatment). At $12 \mathrm{~h}$ after the end of each treatment, uterine samples were collected by flushing and $\mathrm{NO}$ was determined. After nitrate reduction, total nitrite was determined by spectrophotometer. No significant differences on nitric oxide concentration were verified by analysis of variance in the different experimental groups. It is concluded that the use of isoflupredone did not alter the nitric oxide concentration in uterine flushing's from susceptible mares $12 \mathrm{~h}$ after treatment.
\end{abstract}

Keywords: bacterial infection, endometritis, equine, glucocorticoid, NO.

\section{Introduction}

Transient endometritis is a normal consequence of breeding and results from uterine contamination with both semen (Katila et al., 1995) and bacteria (Williamson et al., 1984). Streptococcus equi subsp. zooepidemicus is the pathogen most commonly isolated from the uterus from mares with endometritis (Ferreiro et al., 1986). Normal mares eliminate bacteria, sperm and inflammatory by-products rapidly, in $24-48 \mathrm{~h}$ (Katila, 2008). However, in approximately $10-15 \%$ of Thoroughbred mares this uterine clearance system fails (Zent et al., 1998) and the normally transient inflammation becomes persistent endometritis. These mares are called susceptible to uterine infections (Katila, 2008) causing a substantial economic loss due to low fertility (Troedsson, 2011), and presenting three times more embryonic death rates than in normal mares (Malschitzky et al., 2003).

Increasing evidence shows that differences in the mechanical drainage of the uterus provide the best explanation for susceptibility to uterine infections (Katila, 2008). Susceptible mares presented reduced myometrial activity (Troedsson et al., 1993), delayed physical clearance (LeBlanc et al., 1994), and defects in myometrial function (Rigby et al., 2001). Mucus secretion increases in mares with delayed uterine clearance and bacterial endometritis (Causey et al., 2000). Resistant and susceptible mares have differences in protein composition of their endometrial fluid (Malchitzky et al., 2008) and susceptible mares had an increased intrauterine nitric oxide (NO) production compared to resistant mares (Woodward et al., 2013).

Nitric oxide (NO) is a free gaseous radical (Frean et al., 1997) with a very short half-life (D'Acquisto et al., 1997) of 3 to $5 \mathrm{sec}$ (Rodeberg et al., 1995). This gas causes smooth muscle relaxation (D'Acquisto et al., 1997), including the uterus (Bani et al., 1999). NO synthesis occurs with the oxidation of Larginine (Rodeberg et al., 1995) by the action of the enzyme nitric oxide synthase (NOS). The enzyme NOS converts the terminal guanidine group of L-arginine in NO (Rodeberg et al., 1995). There are at least three isoforms of the enzyme: neuronal NOS (nNOS), endothelial NOS (eNOS), and inducible NOS (iNOS). While nNOS and eNOS are calcium-dependent, iNOS is calcium-independent and produces large amounts of NO (Cameron and Campbell, 1998). Alghamdi et al. (2005) reported the presence of the iNOS expression in uterine biopsies and of NO in uterine secretions of mares resistant and susceptible to endometritis, with higher concentrations being found in susceptible mares. Although it is not clear whether the higher NO is a cause or a result of delayed uterine clearance, the difference between these two groups suggests a possible role for NO in myometrial contractility.

Glucocorticoids are well-recognized antiinflammatory and immunomodulatory agents (Rasmussen et al., 1998). The modulation of the inflammatory response has been proposed as an efficient method for the treatment of endometritis by increasing pregnancy rates with the use of isoflupredone (Dell'Acqua et al., 2006; Papa et al., 2008) and decreasing uterine fluid accumulation (Bucca et al., 2008) with dexamethasone. However, isoflupredone and dexamethasone affected the proteomic profile of the 
endometrial fluid, although the altered proteins are different (Arlas et al., 2014). It has been demonstrated that glucocorticoids inhibit NO production in many cell types and reduce iNOS mRNA levels (Shinoda et al., 2003). Our hypothesis is that the use of isoflupredone reduces uterine NO levels.

The aim of the current study was to determine the effects of isoflupredone, in the presence and absence of a uterine infectious process, on NO levels in uterine samples from mares susceptible to persistent postbreeding endometritis.

\section{Material and Methods}

Mares

Eleven mares (4 to $30 \mathrm{y}$ old) of various breeds, susceptible to endometritis, with endometrial status varying from IIb $(\mathrm{n}=8)$ and III $(\mathrm{n}=3$; Kenney and Doig, 1986), cycling and clinically healthy, were used. Susceptibility was determined after an artificial insemination with $500 \times 10^{6}$ sperm diluted in skim milk (final volume, $20 \mathrm{ml}$ ) according to Malschitzky et al. (2008). Those mares with an intrauterine fluid accumulation $>15 \mathrm{~mm}$ in diameter (based on ultrasonographic examination of the uterus 36 to $48 \mathrm{~h}$ after AI), were classified as susceptible. The mares were part of an experimental herd and were maintained in an open field, supplemented with oats and alfalfa hay, with ad libitum access to water.

\section{Reproductive management}

Mares were given $5 \mathrm{mg}$ prostaglandin F2 $\alpha$ IM (PGF2 $\alpha$; Lutalyse ${ }^{\circledR}$, Pfizer Saúde Animal, Paulínia, SP, Brazil), at $14 \mathrm{~d}$ intervals and estrus was confirmed by transrectal palpation and ultrasonographic examination of the reproductive tract. Once estrus was confirmed (ovarian follicle $>35 \mathrm{~mm}$ in diameter and marked uterine edema), mares were subjected to four treatments (done consecutively, at every second estrus period). To ensure that all mares were in estrus at sample collection, they were routinely examined by transrectal palpation and ultrasonographic examination of the reproductive tract at $12 \mathrm{~h}$ intervals to detect ovulation. If a mare ovulated during treatments, those data were not used.

Before starting each treatment, clinical examinations of the genital tract and endometrial cytology, using a guarded swab, was performed on all mares to ensure that there was no pre-existing endometritis. Only mares without cytological evidence of endometritis (absence of PMNs in the slide at 400X), were used.

\section{Control treatment (control)}

Mares did not receive any treatment.

\section{Glucocorticoid treatment (GC)}

Mares were given $20 \mathrm{mg}$ isoflupredone acetate IM (Predef ${ }^{\circledR}$, Pfizer, Saúde Animal), every 12 h, for three consecutive days, after the mares were confirmed in estrus (Dell'Acqua et al., 2006).

\section{Experimental infection (infected)}

Streptococcus equi subsp. zooepidemicus $(S$. zooepidemicus) was isolated from a mare with clinical signs of endometritis. After isolation, bacteria were cultured in brain heart infusion (BHI) for $24 \mathrm{~h}$. Glycerol was added to the bacteria in BHI bouillon, placed in 2.0 $\mathrm{ml}$ vials (Eppendorf do Brasil, São Paulo, SP, Brazil) which were put directly into a $-20^{\circ} \mathrm{C}$ freezer. Before infusion, bacteria were thawed in a water-bath at $37^{\circ} \mathrm{C}$, cultured in $\mathrm{BHI}$ for $24 \mathrm{~h}\left(37^{\circ} \mathrm{C}\right)$ and seeded onto 100 $\mathrm{mm}$ blood-agar dishes (20-30 dishes). Dishes were incubated at $37^{\circ} \mathrm{C}$ for $24 \mathrm{~h}$ to allow bacterial growth. Dishes were washed with PBS and bacterial colonies were carefully removed. The resulting bacterial suspension was then filtered to remove agar particles and re-suspended in PBS to a final concentration of $1 \mathrm{x}$ $10^{9} \mathrm{CFU} / \mathrm{ml}$. The suspension was placed in $20 \mathrm{ml}$ vials and kept at $5^{\circ} \mathrm{C}$ until use. An insemination pipette was used to infuse the suspension into the uterus.

\section{Glucocorticoid + experimental infection $(G C+$ infected $)$}

Glucocorticoid and S. zooepidemicus infusion were performed as described above, with bacterial cultures being infused $24 \mathrm{~h}$ after the first GC application.

\section{Experimental design}

All mares were submitted to the four treatments and between each treatment they had at least one spontaneous estrous cycle. Since a new element was added for every next treatment, treatment order was as described by Wolf et al. (2012), to ensure that the new element would not affect the next treatment. Treatment 1: control, treatment 2: glucocorticoid (GC), treatment 3: experimental infection (infected) and treatment 4: glucocorticoid + experimental infection $(\mathrm{GC}+$ infected). Before all transvaginal manipulations, the mare's tail was wrapped and the perineal region cleaned with water, neutral detergent and degermant solution (Laboriodine $^{\circledR}$, Segmenta, Ribeirão Preto, Brazil) and dried with a paper towel. To ensure that inflammation was absent before starting the next treatment, at the end of the latest sample collection, mares were treated by uterine washing and intrauterine infusion of $10 \times 10^{6} \mathrm{IU}$ penicillin (Novapen; Marcolab, São João do Paraíso, MG, Brazil) for 5 days. Mares were monitored based on the absence of neutrophils in a uterine swab and the absence of uterine fluid accumulation.

\section{Sample collection}

Endometrial flushings were collected from mares detected in estrus (ovarian follicle $>35 \mathrm{~mm}$ in diameter and marked uterine edema) $12 \mathrm{~h}$ after the end of each treatment (GC and $\mathrm{GC}+$ Infected groups) or infection (infected group). Control treatment mares 
were collected $12 \mathrm{~h}$ after estrus detection. Ovulated mares were excluded from the experiment. For flushing recovery, $100 \mathrm{ml}$ of lactated Ringer solution was infused through the cervix with a Foley catheter (2w30cc24F, Rüsch, Germany). The fluid was distributed to the uterine body and horns by transrectal massage, and recovered by gravity aided by transrectal manipulation of the uterus. Flushings were centrifuged $(1.500 \mathrm{x} g$ for $20 \mathrm{~min})$ to remove all existent cells and the supernatant stored in a freezer at $-80^{\circ} \mathrm{C}$, until use.

\section{Nitric oxide determination}

In order to accurately compare the NO concentration between groups, all samples were frozen sequentially until the collection was completed then analyzed at the same time. Uterine flushing samples were thawed for NO determination by an available commercial kit (Catalogue $\mathrm{n}^{\mathrm{o}}$ ADI-917-010, Stressgen ${ }^{\circledR}$ ), following manufacturer recommendations. Nitrate was converted to nitrite, by the enzyme Nitrate Reductase. After nitrate reduction, total nitrite was determined by spectrophotometer after the addition of Griess reagent to the samples and reading the color absorbance at $540 \mathrm{~nm}$, then calculating the concentration using a standard curve $\left(\mathrm{R}^{2}=0.99\right)$. Samples were run in duplicate. Intra-assay coefficient of variation was $2.4 \%$. Nitric oxide levels were determined in $\mu \mathrm{mol} / 1$. Outliers were defined as $\pm 2 \mathrm{SD}$ from the mean and removed ( 1 of 54 data point, $1.8 \%$ ) from statistical analyses.

\section{Statistical analysis}

NO concentration data in different treatments were submitted to a nonparametric Kruskal-Wallis Test, with significance set at $5 \%$.

\section{Results}

Intrauterine infusion of $S$. zooepidemicus provoked clinical endometritis in all mares, characterized by an accumulation of intrauterine fluid (over $15 \mathrm{~mm}$, as determined by transrectal ultrasonography) before sample collection. No mares used presented evidence of endometritis by cytology nor ovulated before the end of the treatments. NO concentration means did not show difference among treatments $(P=0.22)$ and are described in Table 1 .

Table 1. Means and standard error of NO concentration from uterine flushings in the four treatments (Control, Corticotherapy treatment - GC, Infected and Corticotherapy treatment + experimental infection Infected + GC) from 11 mares.

\begin{tabular}{lc}
\hline Treatments & NO means $(\mu \mathrm{mol} / \mathrm{L}) \pm$ standard error \\
\hline Control & $46.5^{\mathrm{a}} \pm 9.2$ \\
$\mathrm{GC}$ & $68.0^{\mathrm{a}} \pm 26.4$ \\
Infected & $22.1^{\mathrm{a}} \pm 6.7$ \\
Infected + GC & $17.3^{\mathrm{a}} \pm 5.6$ \\
\hline
\end{tabular}

${ }^{\mathrm{a}}$ The same letters in the column represent no significant difference $(\mathrm{P}=0.22)$.

\section{Discussion}

Glucocorticoids are widely used due to their anti-inflammatory and immunodepressive effects (Fang et al., 2007), however pro-inflammatory effects have been attributed to these agents and discrepancies have emerged (Franchimont et al., 1999). Some studies demonstrated that glucocorticoids enhance NO production (Yukawa et al., 2005), while others expressed that they inhibit iNOS expression (D'Acquisto et al., 1997; Pudrith et al., 2010), decreasing NO production. However, these studies examined different isoforms of NOS, which are related to the diverse functions of $\mathrm{NO}$ attributed to its physical and chemical properties and to the range of cells in which it is synthesized (Cameron and Campbell, 1998); therefore, their results cannot be compared. These controversial effects indicate a complex action of glucocorticoids, probably depending on the context in which it is inserted.

Results from the present study demonstrated that isoflupredone therapy did not alter NO concentration in uterine flushings collected in the presence or absence of uterine infection. The modulation of the inflammatory response by isoflupredone has been proposed as efficient for the treatment of endometritis by increasing pregnancy rates (Dell'Acqua et al., 2006; Papa et al., 2008). Isoflupredone act through an immunomodulatory action, inhibiting and stimulating acute phase proteins (APP) in the equine endometrium, mainly when applied in the presence of an inflammatory stimulus, such as infection (Wolf et al., 2012). The isoflupredone therapy increases the presence of apolipoprotein A-1 (ApoA1) in the endometrial fluid after an infection (Wolf et al., 2012). Abundant levels of ApoA-1 have an inhibitory capacity of this APP on production of proinflammatory cytokine IL-1 $\beta$ (Hyka et al., 2001) which is an inducer of iNOS (Persichini et al., 2006). In the same way the IL1 $\beta$ mRNA expression in uterine fluid observed after the use of dexamethasone in mares was lower when compared with control (Woodward et al., 2014). However, no influences in the production of NO were observed. Probably the NO production in susceptible mares after isoflupredone treatment may be regulated by mechanisms other than the IL1 pathway similar to the described after dexamethasone treatments (Woodward et al. 2013).

In spite of the proteomic differences in endometrial fluid (Arlas et al., 2014), isoflupredone and dexamethasone have similar timing peak, varying from 1 to $2 \mathrm{~h}$ (Cross et al., 2011). This quick peak can probably explain the no detection by Fioratti et al. (2010) of differences in NO between control mares and treated with a single administration of dexamethasone 10 and $26 \mathrm{~h}$ before sample collection. In the present experiment uterine fluid was collected $12 \mathrm{~h}$ after the last treatment when isoflupredone action was probably low. Using dexamethasone Christoffersen et al. (2012) observed an increase in gene expression of the proinflammatory cytokine IL- $1 \beta$ (inducer of iNOS) immediately ( $3 \mathrm{~h}$ ) after $E$. coli inoculation. However, no 
effect on the anti-inflammatory cytokine was detected 6 $\mathrm{h}$ after breeding. Probably during 3 to $6 \mathrm{~h}$ the cytokine would have been expressed differently, potentially leading to the decrease in IL1 $\beta$ observed $6 \mathrm{~h}$ after breeding (Woodward et al., 2014). Similar effect can occur with isoflupredone.

Consumption of NO by extravascular parenchymal cells directly depends on oxygen concentration. Conditions of relative hypoxia increase the amount of NO, and the closer NO is to cells, the faster it is removed from the solution. If susceptible mares have an increase in intrauterine fluid as a result of inflammation, then the increased volume in susceptible mares permits for a longer biological life in the uterus (Woodward et al., 2013), as NO needs to travel further to reach the cells (Thomas et al., 2001). Nevertheless, the bacterial infection provoked in this study did not alter the NO concentration when compared with the control mares. Probably in spite of intrauterine fluid and the further travel of NO to the cells, some other source of $\mathrm{O}_{2}$ is present.

It is concluded that the use of isoflupredone did not alter the nitric oxide concentration in uterine flushings from susceptible mares $12 \mathrm{~h}$ after treatment.

\section{Acknowledgments}

The authors are thankful to CNPq, CAPES and FAPERGS for the financial support for this study.

\section{Bioethics and biossecurity committee approval}

All procedures performed were approved by the Ethics Committee on Animal Experiments of the Universidade Federal do Rio Grande do Sul (CEUAUFRGS, project number 22017) in September 19th 2012.

\section{References}

Alghamdi AS, Foster DN, Carlson CS, Troedsson MHT. 2005. Nitric oxide levels and nitric oxide synthase expression in uterine samples from mares susceptible and resistant to persistent breeding-induced endometritis. Am J Reprod Immunol, 53:230-237.

Arlas TR, Wolf CA, Petrucci BPL, Estanislau J, Gregory RM, Jobim MIM, Mattos RC. 2014. Effect of dexamethasone on proteomics of endometrial fluid from mares susceptible to endometritis. J Equine Vet Sci, 34:125-126.

Bani D, Baccari MC, Nistri S, Calamai F, Bigazzi M, Sacchi TB. 1999. Relaxin up-regulates the nitric oxide biosynthetic pathway in the mouse uterus: involvement in the inhibition of myometrial contractility. Endocrinology, 140:4434-4441.

Bucca S, Carli A, Buckley T, Dolci G, Fogarty U. 2008. The use of dexamethasone administered to mares at breeding time in the modulation of persistent mating induced endometritis. Theriogenology, 70:1093-1100.

Cameron IT, Campbell S. 1998. Nitric oxide in the endometrium. Hum Reprod Update, 4:565-569.

Causey RC, Ginn PS, Katz BP, Hall BJ, Anderson
KJ, LeBlanc MM. 2000. Mucus production by endometrium of reproductively healthy mares and mares with delayed uterine clearance. $J$ Reprod Fertil Suppl,56:333-339.

Christoffersen M, Woodward EM, Bojesen AM, Petersen MR, Squires EL, Lehn-Jensen H, Troedsson MH. 2012. Effect of immunomodulatory therapy on the endometrial inflammatory response to induced infectious endometritis in susceptible mares. Theriogenology, 78:991-1004.

D'Acquisto F, Cicatiello L, Iuvone T, Ialenti A, Ianaro A, Esumi H, Weisz A, Carnucestro R. 1997. Inhibition of inducible nitric oxide synthase gene expression by glucocorticoid-induced protein(s) in lipopolysaccharide-stimulated $\mathrm{J} 774$ cells. Eur $J$ Pharmacol, 339:87-95.

Dell'Aqua Jr JA, Papa FO, Lopes MD, Alvarenga MA, Macedo LP, Melo CM. 2006. Modulation of acute uterine inflammatory response after artificial insemination with equine frozen semen. Anim Reprod Sci, 94:270-273.

Fang L, Zhang Y, Lehmann J, Wang Y, Ji H, Ding D. 2007. Design and synthesis of furoxan-based nitric oxide-releasing glucocorticoid derivatives with potent anti-inflammatory activity and improved safety. Bioorg Med Chem Lett, 17:1062-1066.

Ferreiro L, Ferreiro CLR, Mattos RC, Flores WN, Pansard HS, Oliveira LMS. 1986. Flora microbiana do conteúdo uterino de éguas PSI e Quarto-de-Milha a partir de swabs cervicais obtidos no período de 19841986 em haras do RS, PR e SP. Arq Fac Vet UFRGS, 14:45-56.

Fioratti EG, Villaverde AISB, Avanzi BR, Leal ACMS, Caldas-Bussieri MC, Alvarenga MA. 2010. Nitric oxide concentration in free uterine fluid after dexamethasone treatment of mares resistant and susceptible to endometritis. Anim Reprod Sci, 121:S113S114.

Franchimont D, Martens H, Hagelstein MT, Louis E, Dewe W, Chrousos GP, Belaiche J, Geenen V. 1999. Tumor necrosis factor alpha decreases, and interleukin10 increases, the sensitivity of human monocytes to dexamethasone: potential regulation of the glucocorticoid receptor. J Clin Endocr Metab, 84:28342839.

Frean SP, Bryant CE, Fröling I-L, Elliot TJ, Lees P. 1997. Nitric oxide production by equine articular cells in vitro. Equine Vet J, 29:98-102.

Hyka N, Dayer JM, Modoux C, Kohno T, Edwards CK 3rd, Roux-Lombard P, Burger D. 2001. Apolipoprotein A-I inhibits the production of interleukin-1beta and tumor necrosis factor-alpha by blocking contact-mediated activation of monocytes by $\mathrm{T}$ lymphocytes. Blood, 97:2381-2389.

Katila T. 1995. Onset and duration of uterine inflammatory response of mares after insemination with fresh semen. Biol Reprod Mono, 1:515-517.

Katila T. 2008. What do we know about susceptibility of mares to endometritis. Pferdeheilkunde, 24:61-65.

Kenney RM, Doig PA. 1986. Equine endometrial biopsy. In: Morrow DA (Ed.). Current Therapy in Theriogenology. 2nd ed. Philadelphia, PA: WB 
Saunders. pp. 723-729.

LeBlanc MM, Neuwirth L, Asbury AC, Tran T, Mauragis D, Klapstein E. 1994. Scintigraphic measurements of uterine clearance in normal mares and mares with recurrent endometritis. Equine Vet J, 26:109-113.

Cross KP, Paul RI, Goldman RD. 2011. Single-dose dexamethasone for mild-to-moderate asthma exacerbations: effective, easy, and acceptable. Can Fam Physician. 57:1134-1136.

Malschitzky E, Schilela A, Mattos ALG, Garbade P, Gregory RM, Mattos RC. 2003. Intrauterine fluid accumulation during foal heat increases embryonic death. Pferdeheilkunde, 19:246-249.

Malschitzky E, Fiala S, Esmeraldino AT, Neves AP, Garbade P, Jobim MIM, Gregory RM, Mattos RC. 2008. Persistent mating-induced endometritis susceptibility: the role of uterine secretion. Pferdeheilkunde, 24:74-78.

Papa FO, Dell'Aqua Jr JA, Alvarenga MA, Melo CM, Zahn FS, Lopes MD. 2008. Use of corticosteroid therapy on the modulation of uterine inflammatory response in mares after artificial insemination with frozen semen. Pferdeheilkunde, 24:79-82.

Persichini T, Cantoni O, Suzuki H, Colasanti M 2006. Cross-talk between constitutive and inducible NO synthase: an update. Antioxid Redox Sign, 8:949-954.

Pudrith C, Martin D, Kim YH, Jhang, P, Kim B, Wall M, Jung T. 2010. Glucocorticoids reduce nitric oxide concentration in middle ear effusion from lipopolysaccharide induced otitis media. Int $J$ Pediatr Otorh, 74:384-386.

Rasmussen S, Larsena AS, Thomsena ST, Kehlert H. 1998. Intra-articular glucocorticoid, bupivacaine and morphine reduces pain, inflammatory response and convalescence after arthroscopic meniscectomy. Pain, 78:131-134

Rigby SL, Barhoumi R, Burghardt RC, Colleran P, Thompson JA, Varner DD, Blanchard TL, Brinsko SP, Taylor T, Wilkerson MK, Delp MD. 2001. Mares with delayed uterine clearance have an intrinsic defect in myometrial function. Biol Reprod, 65:740-747.

Rodeberg DA, Chaet MS, Bass RC, Arkovitz MS, Garcia VF. 1995. Nitric oxide: an overview. Am J Sur, 170:292-303.

Shinoda J, Mclaughlin KE, Bell HS, Swaroop GR, Yamaguchi S-I, Holmes MC, Whittle AR. 2003. Molecular mechanisms underlying dexamethasone inhibition of iNOS expression and activity in C6 glioma cells. Glia, 42:68-76.

Thomas DD, Liu X, Kantrow SP, Lancaster JR Jr. 2001. The biological lifetime of nitric oxide: implications for the perivascular dynamics of $\mathrm{NO}$ and O2. P Natl Acad Sci USA, 98:355-360.

Troedsson MH, Liu IK, Ing M, Pascoe J, Thurmond M. 1993. Multiple site electromyography recordings of uterine activity following an intrauterine bacterial challenge in mares susceptible and resistant to chronic uterine infection. J Reprod Fertil, 99:307-313.

Troedsson MHT. 2011. Endometritis. In: Mckinnon AO, Squires EL, Vaala WE, Voss JL (Ed.). Equine Reproduction. West Sussex, UK: Wiley-Blackwell. pp. 2608-2619.

Williamson P, Penhale JW, Munyua SJM, Murray J. 1984. The acute reaction of the mares uterus to bacterial infection. In: Abstracts of the 10th International Congress on Animal Reproduction, 1984, UrbanaChampaign, USA. Urbana-Champaign: ICAR. pp. $477-$ 480.

Wolf CA, Malschitzky E, Jobim MIM, Mattos RC. 2012. Effect of corticotherapy on the proteomics of the endometrial fluid from mares susceptible to persistent post-breeding endometritis. Theriogenology, 77:13511359.

Woodward EM, Christoffersen M, Campos J, Horohov DW, Scoggin KE, Squires E, Troedsson MH. 2013. An investigation of uterine nitric oxide production in mares susceptible and resistant to persistent breeding-induced endometritis and the effects of immunomodulation. Reprod Domest Anim, 48:554561.

Woodward EM, Christoffersen M, Horohov D, Squires EL, Troedsson MH. 2014. The effect of treatment with immune modulators on endometrial cytokine expression in mares susceptible to persistent breeding-induced endometritis. Equine Vet $J_{2}$ 47:235239.

Yukawa H, Shen J, Harada N, Cho-Tamaoka H, Yamashita T. 2005. Acute effects of glucocorticoids on ATP-induced $\mathrm{ca}^{2+}$ mobilization and nitric oxide production in cochlear spiral ganglion neurons. Neuroscience, 130:485-496.

Zent WW, Troedsson MHT, Xue J-L. 1998. Postbreeding uterine fluid accumulation in a normal population of Thoroughbred mares: a field study. In: Proceedings of the 44th American Association of Equine Practitioners Convention, 1998, Baltimore, USA. Baltimore, MD: AAEP. pp. 64-65. 